\title{
Karakter Pemimpin dan Hubungannya dengan Kinerja Karyawan PDAM Tirta Daroy Cabang Sultan Iskandar Muda Kota Banda Aceh
}

\author{
Sufyan \\ Akademi Sekretari dan Manajemen Nusantara, Banda Aceh
}

\begin{abstract}
Abstrak. Penelitian ini tentang karakter pemimpin dan bubungannya dengan kinerja karyawan PDAM Tirta Daroy Cabang Sultan Iskandar Muda Kota Banda Aceh. Pengumpulan data menggunakan dua metode yaitu studi kepustakaan (library research) dan studi lapangan (field research. Melalui studi lapangan Peneliti melaksanakan melalui dua teknik yaitu; pengamatan (observasi), yaitu cara pengumpulan data yang dilakukan dengan melihat dan terjun langsung pada rutinitas yang terjadi pada PD AM Tirta Daroy Cabang Sultan Iskandar Muda Kota Banda Aceh dan melalui wawancara (interview), yaitu dengan mengadakan wawancara dengan staffstaff PD AM Tirta Daroy Cabang Sultan Iskandar Muda Kota Banda Aceh. Hasilpenelitian didapati karakter pemimpin PD AM Tirta Daroy Cabang Sultan Iskandar Muda termasuk ke dalam pemimpin yang kurang ideal. Masibnya kurangnya kedisiplinan yang diterapkan oleh pemimpin karena pada saat mengamati keadaan kantor, masib terdapat beberapa karyawan yang datang terlambat. Upaya-upaya yang dapat dilakukan oleh pemimpin PDAM Tirta Daroy Cabang Sultan Iskandar Muda untuk meningkatkan kinerja karyawan adalab pemberian kompensasi kepada karyawan, program pembinaan karyawan, melaksanakan pengawasan langsung dan pengembangan serta peremajaan karyawan.
\end{abstract}

Kata kunci: Karakter Pemimpin, Kinerja Karyawan.

\begin{abstract}
This research is about the character of the leader and its relation to the performance of PDAM Tirta Daroy Branch of Sultan Iskandar Muda of Banda Aceh City. source collection using two methods, literature study (library research) and field study (field research) Through field study researchers perform through two techniques, namely: observation the way source collection is done by looking and plunge directly into the routine that occurs on PDAM Tirta Daroy Branch of Sultan Iskandar Muda Banda Aceh City and through interviens, by conducting interviews with PDAM Tirta Daroy staffs Branch of Sultan Iskandar Muda Banda Aceh City. The results of the research were found to be the leader of PDAM Tirta Daroy Branch of Sultan Iskandar Muda belonging to in less ideal leaders Still lack of discipline applied by the leader because at the time of observing the office situation, there are still some employees who arrived late. Apples that can be done by PD AM Tirta Daroy Branch of Sultan Iskandar Muda to improve employee performance is a compensation, employee guidance programs, direct supervision and development and employee rejuvenation.
\end{abstract}

Keywords: The Caracter of the Leader, Performances.

*Corresponding author. Email: sofyan.ard@gmail.com 


\section{Pendahuluan}

Upaya-upaya untuk meningkatkan kinerja karyawan merupakan tantangan manajemen yang paling serius maka dari itu kinerja seseorang dapat di pengaruhi oleh beberapa faktor. Salah satunya yaitu faktor kepemimpinan untuk mendorong para karyawan untuk mempunyai hasil pekerjaan yang baik serta jumlah pekerjaan yang standar.

Perusahaan Daerah Air Minum (PDAM) Tirta Daroy di Kota Banda Aceh, merupakan salah satu badan usaha penyedia air minum yang bersih dan sehat sesuai dengan peruntukannya untuk dimanfaatkan oleh konsumen. Maka untuk mencapai pada sasaran yang diinginkan oleh perusahaan dalam meningkatkan kinerja karyawan, perlu diperhatikan bagaimana karakter pemimpin yang ada di perusahaan tersebut.

Kepemimpinan yang ada di PDAM Tirta Daroy Cabang Sultan Iskandar Muda Kota Banda Aceh dipimpin oleh seorang Kepala Cabang yang membawahi bagian Seksi Administrasi dan Seksi Tehnik, membutuhkan kepemimpinan yang baik sehingga perusahaan dapat menciptakan pelayanan yang maksimal kepada konsumen yang ada di wilayah pelayanan perusahaan tersebut.

Berdasarkan pengamatan yang dilakukan pada bagian Administrasi PDAM Tirta Daroy masih ditemukan adanya masalah terhadap kepemimpinan yang berhubungan dengan kinerja karyawan pada perusahaan tersebut. Dimana permasalahan yang dihadapi yaitu karakter pemimpin yang kurang luwes dan kerap bertindak menakutkan bagi karyawan namun juga bertindak kurang tegas terhadap karyawan yang melanggar peraturan, menyebabkan karyawan dipenuhi kecemasan, keraguan, dan ketidaknyamanan. Karyawan cenderung lebih terfokus dengan pekerjaan rutinitas dibandingkan berpikir masa depan, karena takut disalahkan.

Dalam hal kedisiplinan masih kurang karena pada saat mengamati keadaan kantor, masih terdapat beberapa karyawan yang datang terlambat dan pada saat jam kantor ada beberapa karyawan yang duduk - duduk di tempat yang diperuntukan untuk penjaga tempat penampungan air. Seharusnya pada saat jam kantor karyawan ada di dalam kantor. Dalam hal pemberian pelayanan kepada konsumen juga berjalan lamban. Hal itu semua terjadi karena kekurang - tegasan dari pemimpin dalam menindak karyawan atau menegur karyawan. Pemimpin juga kurang memberi pengarahan kepada karyawan mengenai peraturan yang harus dipatuhi oleh karyawan.

Dari beberapa persoalan di atas, maka penulisi tertarik untuk meneliti tentang Karakter Pemimpin dan Hubungannya dengan Kinerja Karyawan PDAM Tirta Daroy Cabang Sultan Iskandar Muda Kota Banda Aceh

\section{Tinjauan Literatur}

\section{Pemimpin}

Perkataan pemimpin atau leader memiliki berbagai pengertian. Pemimpin merupakan dampak interaktif dari faktor individu atau pribadi dengan faktor situasi. Fairchild dalam Kartono (2009), menyatakan bahwa pemimpin dalam pengertian luas adalah seorang yang memimpin dengan jalan memprakarsai tingkah laku sosial dengan mengatur, mengarahkan, mengorganisir, mengontrol usaha/upaya orang lain, melalui prestise kekuasaan atau posisi. Sedangakan pemimpin dalam arti terbatas ialah seorang yang membimbing, memimpin dengan bantuan kualitas-kualitas persuasifnya, dan akseptansi/ penerimaan secara sukarela oleh para pengikutnya.

kepemimpinan adalah merupakan suatu kemampuan yang melekat pada diri seorang yang memimpin yang tergantung dari macam macam faktor, baik faktor intern maupun faktor ekstern. Menurut Hasibuan (2012) kepemimpinan merupakan hal yang sangat penting dalam manajerial, karena kepemimpinan maka proses manajemen akan berjalan dengan baik dan pegawai akan bergairah dalam melakukan tugasnya.

Gaya kepemimpinan pada dasarnya mengandung pengertian sebagai suatu perwujudan dari tingkah laku dari seorang pemimpin yang menyangkut dalam kemampuannnya dalam memimpin. Perwujudan tersebut biasanya membentuk suatu 
pola atau bentuk tertentu.

Menurut Stephen P. Robins (2008) terdapat tiga macam model gaya kepemimpinan, yaitu sebagai berikut :

1. Gaya Kepemimpinan Transaksional

Kepemimpinan transaksional adalah pemimpin yang membimbing atau memotivasi para pengikut mereka pada arah tujuan yang telah ditetapkan dengan cara memperjelas peran dan tugas mereka.

2. Gaya Kepemimpinan Transformasi

Kepemimpinan transformasi adalah pemimpin yang menginspirasikan para pengikutnya untuk mengenyampingkan kepentingan pribadi mereka dan memiliki kemampuan memengaruhi yang luar biasa. Kepemimpinan ini lebih unggul dari pada kepemimpinan transaksional dan menghasilkan tingkat upaya dan kinerja para pengikut yang melampaui apa yang bisa dicapai kalau hanya pendekatan transaksional yang diterapkan.

3. Gaya Kepemimpinan Laissez Faire

Gaya kepemimpinan laissez faire dijalankan dengan memberikan kebebasan penuh pada orang yang dipimpin dalam mengambil keputusan dan melakukan kegiatan menurut kehendak dan kepentingan masing-masing baik secara perorangan maupun berupa kelompok kelompok kecil. Laissez faire adalah model yang paling pasif dan karena itu merupakan perilaku pemimpin yang paling tidak efektif. Para pemimpin yang menggunakan ini jarang diangap efektif.

Menurut Kartini Kartono (2006) ada beberapa tipe kepemimpinan, yaitu sebagai berikut :

a. Tipe Karismatis

Tipe pemimpin karismatis ini memiliki kekuatan energi, daya - tarik dan pembawa yang luar biasa untuk mempengaruhi orang lain, sehingga ia mempunyai pengikut yang sangat besar jumlahnya dan pengawal - pengawal yang bisa dipercaya. Sampai sekarang pun orang tidak mengetahui benar sebab-sebabnya, mengapa seseorang itu memiliki karisma begitu besar. Dia dianggap mempunyai kekuatan ghaib (supernatural power) dan kemampuan-kemampuan

yang superhuman, yang diperolehnya sebagai karunia yang Mahakuasa. Dia banyak memiliki inspirasi, keberanian, dan berkeyakinan teguh pada pendirian sendiri.

b. Tipe Paternalistis

Yaitu tipe kepemimpinan yang kebapakan, dengan sifat-sifat antara lain sebagai berikut :

1) Dia menganggap bawahannya sebagai manusia yang tidak/belum dewasa, atau anak sendiri yang perlu dikembangkan.

2) Dia bersikap terlalu melindungi (overly protective).

3) Jarang memberikan kesempatan kepada bawahannya untuk mengambil keputusan sendiri.

4) Dia hampir-hampr tidak pernah memberikan kesempatan untuk kepada bawahan berinisiatif.

5) Dia tidak memberikan atau hampirhampir tidak pernah memberikan kesempatan pada pengikut dan bawahan untuk memgembangkan imajinasi dan daya kreativitas mereka sendiri.

6) Selalu bersikap mahu -tahu dan mahabenar.

c. Tipe Mileteristis

Tipe ini sifatnya sok kemiliter-militeran. Hanya gaya luaran saja yang mencontoh gaya militer. Tetapi jika dilihat lebih seksama, tipe ini mirip sekali dengan tipe kepemimpinan otoriter. Hendaknya dipahami, bahwa tipe kepemimpinan militeristis itu berbeda sekali dengan kepemimpinan organisasi militer (seseorang tokoh militer). Adapun sifat-sifat pemimpin yang militeristis antara lain :

1) Dalam menggerakkan bawahan sistem perintah yang lebih sering dipergunakan.

2) Dalam menggerakkan bawahan senang bergantung kepada pangkat dan jabatannnya.

3) Senang pada formalitas yang berlebihlebihan.

4) Menuntut disiplin yang tinggi dan kaku dari bawahan.

5) Sukar menerima kritikan dari bawahannya.

6) Mengemari upacara-upacara untuk 
berbagai keadaan.

d. Tipe Otokratis

Kepemimpinan otokratis itu mendasarkan diri pada kekuasaan dan paksaan yang mutlak harus dipatuhi. Pemimpinnya selalu mau berperan sebagai pemain tunggal pada a one man show. Dia berambisi sekali untuk merajai situasi. Setiap perintah dan kebijakan ditetapkan tanpa berkonsultasi dengan bawahannya. Anak buah tidak pernah diberi informasi mendetail mengenai rencana dan tindakan yang harus dilakukan. Semua pujian dan kritik terhadap segenap anak buah diberikan atas pertimbangan pribadi pemimpin sendiri.

e. Tipe Laissez Faire

Pada tipe kepemimpinan laissez faire ini sang pemimpin praktis tidak memimpin dia membiarkan kelompoknya dan setiap orang berbuat semau sendiri. Semua pekerjaan dan tanggung jawab harus dilakukan oleh bawahan sendiri. Dia merupakan pemimpin simbol dan biasanya tidak memiliki keterampilan teknis. Pemimpin laissez faire itu pada hakikatnya bukanlah seorang pemimpin dalam pengertian sebenarnya. Sebab bawahan dalam situasi kerja sama sekali tidak terpimpin, tidak terkontrol, tanpa disiplin, masing - masing orang bekerja semau sendiri dengan irama dan tempo "semau gue".

f. Tipe Populistis

Profesor Peter Worsley dalam bukunya The Third World mendefinisikan kepemimpinan populistis sebagai kepemimpinan yang dapat membangunkan solidaritas rakyat. Kepemimpinan populistis ini berpegang teguh pada nilai-nilai masyarakat yang tradisional. Juga kurang mempercayai dukungan kekuatan serta bantuan hutanghutang luar negeri (asing). Kepemimpinan jenis ini mengutamakan penghidupan (kembali) nasionalisme.

g. Tipe Administratif atau Eksekutif

Kepemimpinan tipe administratif ialah kepemimpinan yang mampu menyelenggarakan tugas-tugas administrasi secara efektif. Sedang para pemimpinnya terdiri dari teknokrat dan administratur-administratur yang mampu menggerakkan dinamika modernisasi dan pembangunan. Dengan kepemimpinan administratif ini diharapkan adanya perkembangan teknis yaitu teknologi, industri, manajemen modern dan perkembangan sosial di tengah masyarakat.

h. Tipe Demokratis

Kepemimpinan demokratis berorientasi pada manusia, dan memberikan bimbingan yang efisien kepada para pengikutnya. Terdapat koordinasi pekerjaan pada semua bawahan, dengan penekanan pada rasa tanggung jawab internal (pada diri sendiri) dan kerja sama yang baik. Kekuatan kepemimpinan demokratis ini bukan terletak pada "person atau individu pemimpin", akan tetapi kekuatan justru terletak pada partisipasi aktif dari setiap warga kelompok.

\section{Kinerja}

Landasan yang sesungguhnya dalam organisasi adalah kinerja. Jika tidak ada kinerja maka seluruh bagian organisasi, maka tujuan tidak dapat tercapai. Kinerja perlu dijadikan sebagai bahan evaluasi bagi pemimpin atau manajer. Hadari Nawawi (2006) mengatakan bahwa kinerja adalah sesuatu yang dicapai, prestasi yang diperlihatkan, kemampuan kerja. Sedangkan menurut Malayu S.P. Hasibuan (2007) kinerja adalah hasil kerja yang dicapai seseorang dalam melaksanakan tugas-tugas yang dibebankan kepadanya didasarkan atas kecakapan, pengalaman, kesungguhan waktu.

Secara etimologi, kinerja berasal dari kata prestasi kerja (performance). Sebagaimana dikemukakan oleh A.A. Anwar Prabu Mangkunegara (2007) bahwa istilah kinerja berasal dari kata job performance atau actual performance (prestasi kerja atau prestasi sesungguhnya yang dicapai oleh seseorang) yaitu hasil kerja secara kualitas dan kuantitas yang dicapai oleh seorang pegawai dalam melaksanakan tugasnya sesuai dengan tanggung jawab yang diberikan kepadanya.

\section{Dasar Penilaian Kinerja}

Dasar penilaian kinerja menurut Malayu S.P Hasibuan (2007) adalah uraian pekerjaan dari setiap individu karyawan karena dalam uraian 
pekerjaan inilah, ditetapkan tugas dan tanggung jawab yang akan dilakukan oleh setiap karyawan.

Penilaian menilai pelaksanaan uraian pekerjaan itu baik atau buruk, selesai atau tidak, efektif atau tidak. Tolak ukur yang akan dipergunakan untuk mengukur prestasi kinerja karyawan adalah standar. Sebuah standar dapat dianggap sebagai pengukur yang ditetapkan, sesuatu yang harus diusahakan, sebuah model untuk perbandingan dengan sesuatu alat untuk membandingkan suatu hal dengan hal lain.

Standar penilaian kinerja menurut Malayu S.P Hasibuan (2007) dibagi menjadi dua, yaitu :

a. Tangible Standard

Yaitu sasaran yang dapat ditetapkan alat ukurnya/standarnya. Standar ini dibagi menjadi atas :

1) Standar dalam bentuk fisik yang terbagi atas : standar kualitas, standar kuantitas dan standar waktu.

2) Standar dalam bentuk uang yang terbagi atas : standar biaya, standar penghasilan dan standar investasi.

b. Intangible Standard

Yaitu sasaran yang tidak dapat ditetapkan alat ukur karyawan terhadap perusahaan. Misalnya standar perilaku, kesetiaan, partisipasi dan dedikasi. Dengan penentuan standar untuk berbagai keperluan maka timbulah apa yang disebut "standarisasi" yaitu penentuan dan penggunaan berbagai ukuran, tipe, gaya tertentu dan sebagainya berdasarkan suatu komposisi standar sebagai alat ukur hasil yang dicapai dan perilaku yang dilakukan baik di dalam maupun di luar pekerjaan karyawan.

\section{Karyawan}

Setiap Perusahaan membutuhkan karyawan sebagai tenaga yang menjalankan setiap aktivitas yang ada dalam organisasi perusahaan. Karyawan merupakan asset terpenting yang memilki pengaruh sangat besar terhadap kesuksesan sebuah perusahaan. Tanpa mesin canggih, perusahaan dapat terus beroperasi secara manual, akan tetapi tanpa karyawan, perusahaan tidak akan dapat berjalan sama sekali.
Jika diartikan secara sederhana, karyawan dapat diartikan sebagai setiap orang yang memberikan jasa kepada perusahaan ataupun organisasi yang membutuhkan jasa tenaga kerja, yang mana dari jasa tersebut, karyawan akan mendapatkan balas jasa berupa gaji dan kompensasi-kompensasi lainnya.

Karyawan tentunya bertugas sesuai yang telah di tentukan oleh pimpinan atau atasannya. Umumnya karyawan bekerja tinggal melaksanakan tugas-tugas yang sudah di instruksikan saja, atau terkadang bisa juga mengekspresikan kreatifitasnya sesuai yang memberi instruksi saat bekerja. Kegesitan, ketepatan, ketelitian maupun kerapihan dalam bekerja merupakan hal-hal yang perlu di perhatikan oleh setiap karyawan, karena umumnya hal-hal seperti itu dapat menentukan penilaian karyawan oleh seorang pimpinan. Yang sering menjadi perhatian adalah ketepatan waktu atau kedisiplinan dalam bekerja, banyak sekali perusahaan yang sangat mementingkan hal tersebut dalam menilai karyawannya.

Relatif tidak sulit untuk menjadi seorang karyawan, jika sudah terbiasa dengan pekerjaan maka tidak perlu terlalu banyak berfikir mencari cara untuk memecahkan masalah dalam pekerjaan, karena biasanya pekerjaan yang dilakukan seperti rutinitas sehari-hari atau pekerjaan yang dilakukan hanya itu-itu saja. Tapi ada beberapa bidang tertentu yang dimana karyawan di haruskan untuk memecahkan permasalahan tertentu, tapi permasalahan tersebut tidaklah terlalu kompleks, karena semakin kompleks permasalahan akan ditangani oleh orang yang levelnya lebih tinggi dalam pekerjaan.

Di suatu tempat kerja biasanya ada beberapa karyawan yang dapat di katakan menonjol atau memiliki kemampuan yang lebih dalam memecahkan masalah, pimpinan pasti dapat menilai dan membedakan karyawan seperti itu dan tentunya memiliki nilai yang lebih di matanya. Biasanya jika ada karyawan yang memiliki kemampuan lebih akan mendapatkan kesempatan untuk mengembangkan dirinya lagi misalnya seperti diberikan biaya untuk kuliah lagi sehingga bisa naik jabatan di tempat dia bekerja. 


\section{Metodologi Penelitian}

Dalam penelitian ini, penulis menggunakan 2 (dua) metode dalam pengumpulan data, di antaranya :

a. Studi Kepustakaan (Library Research), yakni dengan bahan-bahan kuliah dan teori yang bersumber dari text book bahan kuliah, dan laporan-laporan yang berhubungan dengan praktek kerja yang merupakan data sekunder, serta dengan membaca buku-buku perpustakaan yang ada hubungannya dengan pembahasan.

b. Studi Lapangan (Field Research), yakni proses pengumpulan data yang dilakukan secara langsung dari lapangan melalui penelitian yang dilaksanakan selama 3 (tiga) bulan pada PDAM Tirta Daroy Cabang Sultan Iskandar Muda Kota Banda Aceh.

Dalam melaksanakan metode ini, penulis melakukan 2 teknik yaitu :

a. Pengamatan (observasi), yaitu Cara pengumpulan data yang dilakukan dengan melihat dan terjun langsung pada rutinitas yang terjadi pada PDAM Tirta Daroy Cabang Sultan Iskandar Muda Kota Banda Aceh.

b. Wawancara (interview), yaitu dengan mengadakan wawancara dengan staff-staff PDAM Tirta Daroy Cabang Sultan Iskandar Muda Kota Banda Aceh.

\section{Hasil dan Pembahasan}

\section{Sejarah Singkat PDAM Tirta Daroy Cabang SIM}

Perusahaan Daerah Air Minum (PDAM) Tirta Daroy Kota Banda Aceh ditetapkan berdasarkan Perda No. 2 Tahun 1975 berdiri pada tanggal 24 Februari 1975. Aceh. PDAM Tirta Daroy Kota Banda Aceh merupakan satusatunya perusahaan penyedia air bersih untuk kebutuhan masyarakat di Ibukota Provinsi Aceh. Di samping itu juga untuk memenuhi kebutuhan air bersih bagi pelayanan publik lainnya seperti Industri Pariwisata, Rumah Sakit, Perdagangan dan Jasa, Pasantren dan sebagainya.

Pasca bencana gempa dan tsunami pada tanggal 26 desember 2004, berbagai bantuan rekonstruksi infrastruktur telah dilaksanakan di Kota Banda Aceh termasuk infrastruktur sistem penyedia air bersih berupa infrastruktur pengolahan, jaringan perpipaan maupun bantuan manajemen yang meliputi peningkatan sumber daya manusia dan lainnya.

Berkaitan dengan hal tersebut PDAM Tirta Daroy Kota Banda Aceh pasca bencana mengalami perubahan profil perusahaan baik dibidang teknis maupun administrasi keuangan seperti meningkatnya persentase cakupan pelayanan dan menurunnya tingkat kerugian secara bertahap.

Sistem penyediaan air minum di Kota Banda Aceh saat ini dikelola oleh PDAM Tirta Daroy Kota Banda Aceh. Sistem air perpipaan yang melayani penduduk Kota Banda Aceh adalah menggunakan sumber air Krueng Aceh. PDAM Tirta Daroy Cabang Sultan Iskandar Muda Kota Banda Aceh saat ini memiliki daerah pelayanan, yaitu meliputi pelayanan di Kecamatan Meuraxa, Baiturrahman (hanya sebagian kelurahan), Kuta Raja, dan Jaya Baru.

\section{Struktur Organisasi PDAM Tirta Daroy Cabang SIM}

Dalam mengantisipasi permasalahan sistem penyediaan air bersih yang semakin kompleks, serta adanya komitmen manajemen perusahaan yang akan terus berupaya meningkatkan kualitas pelayanan dengan lebih berorientasi kepada pelanggan.

Sesuai dengan struktur organisasi PDAM Tirta Daroy Cabang Sultan Iskandar Muda Kota Banda Aceh, maka setiap tingkatan memiliki tugas dan fungsi masing-masing. Adapun tugas dan fungsi setiap tingkatan dalam struktur organisasi adalah sebagai berikut :

a. Direktur Utama

Direktur Utama mempunyai tugas pokok yaitu memimpin, mengkoordinasi, mengelola dan mengendalikan serta merencanakan teknis operasional pengelolaan Perusahaan Daerah sesuai dengan qanun dan Rencana Kerja Anggaran PDAM.

b. Kepala Cabang

Kepala cabang mempunyai tugas yaitu mengendalikan kegiatan dalam bidang 
tehnik dan bidang administrasi yang berlangsung di PDAM Tirta Daroy Cabang Sultan Iskandar Muda Taman Sari.

c. Bagian Seksi Tehnik

Bagian Seksi Tehnik memiliki tugas yaitu :

1) Melakukan Pemutusan tunggakan rekening.

2) Melakukan Pemutusan Ilegal.

3) Melakukan Penyambungan kembali.

4) Melakukan Penyambungan kembali setelah 3 (tiga) bulan.

5) Melakukan Pergantian Water meter rusak, kabur, tertimbun.

6) Melakukan Perbaikkan Pipa Bocor $\leq$ $\varnothing 75 \mathrm{~mm}$.

7) Melakukan Penyambungan Sambungan Baru (SR).

8) Menyelesaikan pengaduan masyarakat terhadap ganguan di lapangan.

9) Mengoptimalisasi aliran air di 3 (tiga) kecamatan dibawah wilayah cabang II taman sari.

10) Melakukan Pemetaan pelanggan yang aktif dan in aktif wilayah cabang II.

11) Melakukan invetalisir water meter rusak, kabur, tertimbun.

12) Membuat laporan kegiatan lapangan seksi Tehnik.

13) Menerima laporan masyarakat terhadap gangguan di lapangan.

14) Menginput data pelanggan aktif dan in aktif ke dalam peta jaringan PDAM Tirta Daroy.

d. Bagian Seksi Administrasi

Bagian Seksi Administrasi memiliki tugas yaitu :

1) Melakukan inventarisir pelanggan yang tertunggak rekening air.

2) Melakukan teguran bagi pelanggan yang tertunggak rekening air.

3) Melakukan penagihan terhadap pelanggan yang tertunggak rekening air.

4) Pelayanan loket pembayaran cabang II (Cabang Sultan Iskandar Muda).

\section{Karakter Pemimpin PDAM Tirta Daroy Cabang SIM}

Seorang pemimpin adalah individu dengan jiwa yang terlatih dan mampu melatih individuindividu lain untuk mewujudkan visi yang bersifat seragam. Seorang pemimpin diharuskan mampu melibatkan diri dalam unsur keberagaman sifat anggota yang menjadi tanggung jawabnya. Pemimpin yang ideal adalah pemimpin yang mampu membawa misi kelompoknya ke arah yang baik dan tetap teguh merangkul semua anggota kelompok, yang memenuhi karakter sebagai berikut;

a. Cerdas

Kecerdasan merupakan point utama yang menentukan seberapa baik langkah yang diambil oleh seorang pemimpin jika dihadapkan oleh suatu masalah kelompok. Pemimpin ideal adalah pemimpin yang cerdas dalam membawa diri yang didukung dengan keunggulan berfikir dan peka terhadap hal-hal sekitar.

b. Berinisiatif

Pemimpin berani berinisiatif jika dihadapkan dengan suatu masalah. Inisiatifme diri jelas dibutuhkan oleh seorang pemimpin demi terciptanya solusi yang bersifat nyata dan menjanjikan. Pemimpin yang berinisiatif adalah pemimpin yang mampu menggerakkan dirinya sendiri terlebih dahulu untuk memulai segala sesuatunya tanpa adanya paksaan.

\section{Simpulan dan Saran}

\section{Kesimpulan}

Karakter pemimpin PDAM Tirta Daroy Cabang Sultan Iskandar Muda termasuk ke dalam pemimpin yang tidak ideal. Masihnya kurangnya kedisiplinan yang diterapkan oleh pemimpin karena pada saat mengamati keadaan kantor, masih terdapat beberapa karyawan yang datang terlambat. Upaya-upaya yang dilakukan oleh pemimpin PDAM Tirta Daroy Cabang Sultan Iskandar Muda untuk meningkatkan kinerja karyawan adalah pemberian kompensasi kepada karyawan, program pembinaan karyawan, melaksanakan pengawasan langsung dan pengembangan serta peremajaan karyawan.

\section{Saran}

Pimpinan Kantor PDAM Tirta Daroy Cabang Sultan Iskandar Muda harus mempunyai karakter pemimpin yang Ideal agar karyawan yang dipimpinnya lebih leluasa dan nyaman dalam bekerja dan Kepemimpinan yang dijalankan harus penuh keteladanan dan berkualitas. Jika pemimpin memaksa karyawan untuk melakukan sesuatu sekarang juga dengan sesempurna 
mungkin, maka pemimpin harus melakukan hal tersebut terlebih dahulu di depan karyawannya

\section{Daftar Pustaka}

A.A. Anwar Prabu Mangkunegara. 2007. Evaluasi Kinerja Sumber Daya Manusia. Bandung: Penerbit Refika Aditama.

Azkira Ibrahim. 2013. Artikel Pengertian Karyawan dan Jenis - jenis Karyawan di Perusahaan. Diberdayakan oleh blogger.

Hadari Nawawi. 2006. Evaluasi Dan Manajemen Kinerja di Lingkungan Perusahaan dan Industri. Yogyajarta: Gadjah Mada University Press.

Kartini Kartono. 2009. Pemimpin dan Kepemimpinan. Jakarta: PT Raja Grafindo Persada.

M. Manullang. 2002. Manajemen Personalia. Yogjakarta: UGM Press.

Malayu S.P. Hasibuan. 2007. Manajemen Sumber Daya Manusia Edisi Revisi. Jakarta: Bumi Aksara.

. 2012. Manajemen Sumber Daya Manusia. Jakarta: Bumi Aksara.

Marihot Tua Efendi Hariandja. 2009. Manajemen Sumber Daya Manusia. Jakarta: Grafindo.

Miftah Thoha. 2006. Kepemimpinan dalam Manajemen. Jakarta: Raja Grafindo Persada.
Muhammad Fajar Purnomo. "Pengaruh Kepemimpinan, Motivasi, Dan Disiplin Kerja Terhadap Kinerja Karyawan PDAM Tirta Moedal Semarang". Universitas Dian Nuswantoro, Semarang-Indonesia.

R.L Mathis \& J.H. Jackson. 2006. Human Resource Management: Manajemen Sumber Daya Manusia. Terjemahan Dian Angelia. Jakarta: Salemba Empat.

Rinda Suryani. 2014. "Prosedur Penggunaan Kartu Perhitungan Rekening Air Pelanggan Kota Banda Aceh Pada PDAM Tirta Daroy". STMIK UBudiyah Indonesia, Banda Aceh-Indonesia.

Rivai Veithzal dan Basri. 2005. Performance Appraisal: Sistem Yang Tepat Untuk Menilai Kinerja Karyawan Dan Meningkatkan Daya Saing Perusahaan. Jakarta: Raja Grafindo Persada.

Rivai Veithzal dan Deddy Mulyadi. 2011. Kepemimpinan dan Perilaku Organisasi. Jakarta: Raja Grafindo Persada.

Sitty Yuwalliatin. 2006. "Pengaruh Budaya Organisasi, Motivasi, dan Komitmen Terhadap Kinerja Serta Pengaruhnya Terhadap Keunggulan Kompetitif Dosen Unisulla Semarang". EKOBIS Vol. 7 No. 2, Juni, h. 69-84.

Stephen P. Robbins. 2008. Organizational Behavior, Tenth Edition (Perilaku Organisasi Edisi ke sepuluh), Alih Bahasa Drs. Benyamin Molan. Jakarta : Salemba Empat. 